\title{
Plant characters of broccoli determinants of head production
}

\author{
Caracteres de plantas do brócolis determinantes da produção de cabeça
}

\author{
Fernanda Daniela Brandelero ${ }^{I^{*}}$ Betania Brum $^{\mathrm{I}}$ Lindolfo Storck $^{\mathrm{I} \text {, II }}$ Jessica Cardoso ${ }^{\mathrm{I}}$ \\ Talita Slota Kutz ${ }^{I}$ Thiago de Oliveira Vargas ${ }^{I}$
}

\section{ABSTRACT}

The increasing consumption of single-head broccoli is due to several factors, among them there are food production in minimally processing form and the existence of hybrids that adapt to various climates, in addition to the simple harvesting of this typical architecture.This study aimed to identify the most relevant plant characters of broccoli, represented by growth characters, which are determinant in the production and canopy area. The study was conducted in an experimental area in Pato Branco city, PR. The 11 characters were evaluated for 365 plants, spaced with $0.8 \times 0.5 \mathrm{~m}$, on a blank experiment. The characters of group 1 (height, number of leaves, stem height, stem diameter) were evaluated on the 21 and 58 day after transplanting (DAT), and the leaf area was evaluated on the 17 and 32 DAT. The characters of group 2 were quantity of fresh head mass and canopy area. At the initial stage of cultivation, on the 17 and 21 DAT, variations in the plants characters did not lead toany variation in production. The higher number of leaves and the larger stem diameter on the 58 DAT determined the greater mass of the broccoli heads.

Key words: Brassica oleracea var. italica, linear relationships, canonical correlation, growth variables.

\section{RESUMO}

O aumento do consumo do brócolis de cabeça única é devido à produção do alimento na forma minimamente processada e ao surgimento de híbridos com adaptação a climas variados, além da facilidade de colheita com esse tipo de arquitetura. Objetivou-se identificar os caracteres de maior relevância da planta de brócolis, representadas por caracteres de crescimento, que são determinantes da produção e da área do dossel. $O$ experimento foi conduzido em área experimental no município de Pato Branco, PR. Os 11 caracteres foram avaliados em 365 plantas, espaçadas em 0,8x0,5m, sobre um experimento em branco. Os caracteres do grupo 1: altura, número de folhas, altura de caule, diâmetro de caule, foram avaliados aos 21 e aos 58 dias após o transplante (DAT); a área foliar foi avaliada aos 17 e 32 DAT. Os caracteres do grupo 2 foram: Massa da matéria fresca de cabeça e área do dossel. Nas fases iniciais da cultura, aos 17 e 21 DAT, as variações das características da planta não influenciam na variação da produção. Maior número de folhas e maior diâmetro do caule aos 58 dias após transplante determinam maior massa de cabeça de brócolis.

Palavras-chave: Brassica oleracea var. italica, relações lineares, correlação canônica, variáveis de crescimento.

\section{INTRODUCTION}

Broccoli is a plant with low calorie level, and full of nutrients and fibers, being highly recommended for human nutrition (KRAUSE \& MAHAN, 2005; CARVALHO et al., 2006; ALVES et al., 2011). The demand for single-head broccoli (Brassica oleracea L. var. italic Plenck) has increased in the last few years (FERREIRA et al., 2013), due to the development of hybrids with a higher adaptability to diverse sites, improved production and sensory quality, as well as goodvisual attractiveness.

Harvesting of single-head broccoli is easier because there is only one harvesting cut, while the "branchy" broccoli needs several harvesting. Consequently, "branchy" broccoli demands more labor, which can be scarce in small properties. In

\footnotetext{
IDepartamento de Ciências Agrárias, Universidade Tecnológica Federal do Paraná (UFTPR), Via do Conhecimento, Km 1, 85503-390, Pato Branco, PR, Brasil. E-mail: fernanda_brandelero@hotmail.com. "Corresponding author.

"Programa de Pós-graduação em Agronomia, Universidade Federal de Santa Maria (UFSM), Santa Maria, RS, Brasil
} 
regions where family agriculture prevails, diversity in production is very important to increase income (GODOY \& RECH, 2013).

Due to this higher demand, the varieties of broccoli that are more adaptable to the climate of each region are identified, with special attention to what plant traits determine as higher productivity of heads. In order to observe these traits, scientists can measure the plants in different phenological stages of the crop to obtain the best relationship between groups of characters (BRUM et al., 2011). Therefore, Pearson's (r) linear correlation coefficient can be used to study the relationship between two random variables, expressing the meaning and the relationship strentgh between them (FERREIRA, 2009).

Additional studies may be conducted, such as the canonical correlation, which evaluates the interrelations between two sets of characters (CRUZ \& REGAZZI, 1997). This method is used when the study involves more than one variable in each set of variables, particularly in exploratory studies, where the multiple relationships between the variables are unknown (CARVALHO et al., 2004; SILVA et al., 2007; RIGÃO et al., 2009).

There are numerous studies that apply canonical correlation, for example, with eucalyptus (CASTRO et al., 2013), potato (RIGÃO et al., 2009), red pepper (TAVARES et al., 1999), castor bean (BRUM et al., 2011) and corn (CARGNELUTTI FILHO et al., 2010). However, studies that show the correlations between growth and production factors in the cultivation of broccoli are unknown, and may be useful to establish procedures for crop management. Production factors of this crop are the mass of broccoli head and the head diameter. Growth factors are related to the plant characteristics before harvest. Identification of growth factors that determine production, during the plant's development, allows the best management intervention to achieve better production. Thus, this study aimed to identify the most relevant plant characters of broccoli, represented by growth characters, which are determinant in the production and canopy area.

\section{MATERIALS AND METHODS}

The study was conducted in the experimental area of the Universidade Tecnológica Federal do Paraná (UTFPR), Pato Branco, PR $\left(26^{\circ} 10^{\prime} \mathrm{S}\right.$ and $\left.52^{\circ} 41^{\prime} \mathrm{W}\right)$. The soil is characterized as dystrophic Red Latosol (EMBRAPA, 2006). Climate is considered humid subtropical $\mathrm{Cfa}$, according to the Köppen classification (MAACK, 1968), with an average altitude of 760 meters. The chemical analysis of the soil $(0-0.20 \mathrm{~m})$ of the experimental area in the beginning of the experiment resulted in the following characteristics: $63.0 \mathrm{~g} \mathrm{dm}^{-3}$ of $\mathrm{MO}$ (Walkley-Black); 7.4mg dm $\mathrm{m}^{-3}$ of $\mathrm{P}$ (Mehlich I); $0.30 \mathrm{cmolc}^{-3}$ of $\mathrm{K}$ (Mehlich I); $\mathrm{pH}$ em $\mathrm{CaCl} 2$ (1:2.5) 5.30; $0.01 \mathrm{cmolc} \mathrm{dm}^{-3} \mathrm{Al}^{+3} ; 5.05 \mathrm{cmolc} \mathrm{dm}^{-3}$ de $\mathrm{Ca} ; 3.72 \mathrm{cmolcdm}^{-3}$ de $\mathrm{Mg}(\mathrm{KCl} 1 \mathrm{M})$.

Cultivation took place between October and December of 2013. The maximum and minimum temperatures observed during the experiment were $25.4^{\circ} \mathrm{C}$ and $15.0^{\circ} \mathrm{C}$, respectively. The experiment was conducted in blank, where treatments are not evaluated, comprising a total area of $1344 \mathrm{~m}^{2}$, with a useful area of $940 \mathrm{~m}^{2}$.

In order to conduct a blank experiment, the soil was previously prepared with the use of a rotary hoe. Next, furrows spaced with a $0.8 \mathrm{~m}$ were made and, further, the lines were submitted to basic fertilization. Doses applied were $39.37 \mathrm{~kg} \mathrm{ha}^{-1}$ of $\mathrm{N}$, $180 \mathrm{~kg} \mathrm{ha}^{-1}$ of $\mathrm{P}_{2} \mathrm{O}_{5}$ and $75 \mathrm{~kg} \mathrm{ha}^{-1}$ of $\mathrm{K}_{2} \mathrm{O}$, administered in the form of urea, single superphosphate and potassium chloride. The phosphorus was entirely applied to the furrows at transplanting and the nitrogen and potassium were parceled, with $1 / 3$ applied at transplanting, $1 / 3$ on the 20 and $1 / 3$ on the 44 days after transplanting (DAT), according to the recommendation of the Soil Fertilization Commission and the results obtained from the soil analysis. In the first top dressing fertilization (20 DAT), the fertilizer was superficially incorporated, with ridging to increase the plants' sustention. Three foliar applications of the following micro-nutrients were performed: boron (B), in the form of boric acid $\left(1 \mathrm{~g} \mathrm{~L}^{-1}\right)$ and molybdenum (Mo) in the form of sodium molybdate $\left(0.5 \mathrm{~g} \mathrm{~L}^{-1}\right)$.

Seedlings of the hybrid broccoli BRO $68^{\circledR}$, with single-head production features, were produced in trays of 128 cells, with commercial substrate, inside a greenhouse. The transplanting to the experimental field was performed when the seedlings had already reached the average height of $8.8 \mathrm{~cm}$ (46 days after sowing and with the presence of 4 to 5 true leaves), with a space of $0.5 \mathrm{~m}$ between plants.

Inside the useful area, 40 groups of 10 sequential plants were randomly marked, comprising 400 plants that were used for evaluation. Two groups of traits were considered (Group 1 and Group 2). Characters in Group 1 were: a) plant height (PH), in $\mathrm{cm}$, measured from the soil level to the apical bud; b) number of completely expanded green leaves 
(NL); c) stem height ( $\mathrm{SH})$, in $\mathrm{cm}$, measured from the insertion of the stem into the soil until the basis of leaf primordia; d) stem diameter (SD), in $\mathrm{mm}$, measured with a digital caliper rule, at $2.0 \mathrm{~cm}$ below the apical bud; e) leaf area (LA), obtained from the longer and wider linear measures, in $\mathrm{dm}^{2}$, using the formula described by OLFATI et al. (2010), collected on the 17 and 32DAT. For characters a), b), c) and d), values from two dates were considered: the 21 and 58DAT, according to DINIZ et al. (2008). Characters in Group 2 were: a) mass of fresh matter of broccoli heads (HM), being the broccoli head cut at $2.5 \mathrm{~cm}$ of the peduncle from the last insertion in the inflorescence, and immediately evaluated to avoid water loss; b) canopy area (CA) in the crop was calculated based on the superior transversal and longitudinal average radius of the canopy throughout the plantation line according to the methodology described by DINIZ et al. (2008).

Harvesting of broccoli heads and the evaluations of characters of Group 2 were done on the 60 day after transplanting for all plants, regardless of the head's development. From the 400 plants evaluated, the samples that had any decease or showed some kind of anomaly were excluded, leaving 365 plants with appropriate characteristics for consumption.

For each character, the average, minimum and maximum values, variance, standard deviation and coefficient of variation were estimated. Parson's linear correlation coefficients were calculated between all pairs of characters. Analysis of the multiple co-linearity of the linear correlation's matrix, within each group of characters, was performed using the criterion of the number of conditions, with the purpose of reducing the disturbing effect of the co-linearity on the estimates of the canonical pairs' coefficients (MONTGOMERY et al., 2006). Afterwards the canonical correlation between the two groups of traits was carried out (CRUZ \& REGAZZI, 1997; RIGÃO et al., 2009). In this analysis, the number of significant canonical correlations was identified, together with the respective coefficients for the canonical pairs. The canonical correlation is a multivariate statistical analysis that allows the examination of the structure of the relationship between two groups of variables (X and $\mathrm{Y}$ ), verifying the existence and intensity of linear associations between the two groups, expressed by $\left(\mathrm{X}_{1} \mathrm{X}_{2} \mathrm{X}_{3} \ldots \mathrm{X}_{\mathrm{p}}\right)$ and $\left(\mathrm{Y}_{1} \mathrm{Y}_{2} \mathrm{Y}_{3} \ldots+\mathrm{Y}_{\mathrm{q}}\right)$. A linear combination is developed for the canonical correlation, for each one of the sets of variables (X and $\mathrm{Y}$ ), so the association is maximized, with no identification of dependence between groups. For the interpretation, it was considered that characters with high coefficients (positive or negative) in a group are determining characters with high coefficients in the other group (MORRISON, 1978). For the analysis it was used the Genes program (CRUZ, 2013).

\section{RESULTS AND DISCUSSION}

The average mass of the production of harvested broccoli heads (HM) obtained in this study $\left(1187.5 \mathrm{~g} \mathrm{head}^{-1}\right)$, is superior to the one obtained by LALLA et al. (2010), for the same hybrid (482.6g head $\mathrm{g}^{-1}$ ). However, MELO et al. (2010) obtained a mass varying between 172.7 and 457.5 $\mathrm{g} \mathrm{head}^{-1}$, and CAMPAGNOL et al. (2009) reported a mass of $615 \mathrm{~g} \mathrm{head}^{-1}$. Results of this study are similar to the value obtained by SEABRA JUNIOR et al. (2014), where, with the same hybrid, the mass reported was of $907 \mathrm{~g} \mathrm{head}^{-1}$, a result that is similar to the one obtained by TREVISAN (2013), where the mass was $864.4 \mathrm{~g} \mathrm{head}^{-1}$. This indicates the high productive potential of the hybrid. As a consequence, it is possible to deduce that the data obtained is adequate for the study proposed.

The ridging performed on the 20DAT, may have been the cause of the high coefficient of variation $(\mathrm{CV}=26.9 \%)$ observed for stem height on the 21DAT (SH21, Table 1). The variability of this character decreased on the 58DAT $(\mathrm{CV}=9.2 \%)$ due to the natural erosion of the ridging, used as a reference to measure the height. The great variation for the character mass of the broccoli head, at harvest, was due to the occurrence of only one harvesting date for the whole experimental area, which resulted in a greater variability of the plants caused by non-controlled environmental factors. Several development criteria for the head, used to determine the harvesting time, were studied (TREVISAN et al., 2003; SEABRA JUNIOR et al., 2014). Considering that the harvest was done when the heads were, on average, near the optimum point for harvest, the variability among the heads was higher than if each unit was picked exactly at its optimum point. Percentage of heads with masses below $500 \mathrm{~g}$ was $1.36 \%$, conversely, $23.8 \%$ of heads had a mass between 500 and $1000 \mathrm{~g}, 61.6 \%$ between 1000 and $1500 \mathrm{~g}$ and $13.1 \%$ above $1500 \mathrm{~g}$.

According to the spacing used, the area available for each plant was $40 \mathrm{dm}^{2}$ per plant, however the average observed for the canopy area was higher $\left(46.7 \mathrm{dm}^{2}\right)$. It is possible to conclude that this superior value of the space provided to each 
Table 1 - Average, minimum and maximum value, coefficient of variation (CV), variance and standard deviation (sd) of 365 plants, for characters of broccoli BRO $68^{\circledR}$ hybrid.

\begin{tabular}{|c|c|c|c|c|c|c|}
\hline Char $^{(1)}$ & Average & Minimum & Maximum & $\mathrm{CV}$ & Variance & $\mathrm{sd}$ \\
\hline HM & 1187.2 & 130.0 & 2026.0 & 23.8 & 80093.1 & 283.1 \\
\hline $\mathrm{CA}$ & 46.76 & 6.7 & 70.6 & 22.1 & 106.9 & 10.3 \\
\hline PH21 & 16.8 & 9.0 & 24.0 & 14.9 & 6.3 & 2.5 \\
\hline PH58 & 56.9 & 38.0 & 75.0 & 10.5 & 36.3 & 6.0 \\
\hline NL21 & 8.1 & 6.0 & 10.0 & 9.7 & 0.6 & 0.7 \\
\hline NL58 & 16.9 & 11.0 & 22.0 & 12.4 & 4.4 & 2.1 \\
\hline SH21 & 3.6 & 2.0 & 6.5 & 26.9 & 0.9 & 0.9 \\
\hline SH58 & 25.3 & 18.0 & 33.0 & 9.2 & 5.4 & 2.3 \\
\hline SD21 & 14.3 & 7.8 & 18.9 & 12.6 & 3.2 & 1.8 \\
\hline SD58 & 48.8 & 29.1 & 68.3 & 11.9 & 33.9 & 5.8 \\
\hline LA17 & 50.1 & 36.7 & 63.9 & 9.3 & 21.6 & 4.6 \\
\hline LA32 & 106.7 & 74.4 & 148.1 & 12.4 & 175.8 & 13.3 \\
\hline
\end{tabular}

${ }^{(1)} \mathrm{HM}$ - head mass at harvesting (g); CA - canopy area $\left(\mathrm{dm}^{2}\right)$; PH21 - plant height on the 21 day after transplanting (cm); PH58 - plant height on the 58 DAT $(\mathrm{cm})$; NL21 - number of leaves on the 21 DAT; NL58 - number of leaves on the 58 DAT; SH21 - stem height on the 21DAT (cm); SH58 - stem height on the 58 DAT (cm); SD21 - stem diameter on the 21 DAT (mm); SD58 - stem diameter on the 58 DAT $(\mathrm{mm})$; LA 17 - leaf area $\left(\mathrm{dm}^{2}\right.$ plant $\left.^{-1}\right)$ on the 17 DAT; LA32 - leaf area $\left(\mathrm{dm}^{2}\right.$ plant $\left.{ }^{-1}\right)$ on the 32 DAT.

plant is due to their rearrangement, where leaves end up super imposing each other to search for more light, as observed by DINIZ et al. (2008). Based on the results shown by the coefficients of variation, there is no indication that a character should be excluded for lack of variability, according to the description provided by BRUM et al. (2011).

Among the simple correlation coefficients between the plant's characters and the production of broccoli (Table 2), most coefficients were significant, as 45 of the 60 coefficients observed $(75 \%)$. From these, $32(48 \%)$ are considered weak $(0<\mathrm{r}<0.3), 12(20 \%)$ average $(0.3<\mathrm{r}<0.6)$ and, only one $(2 \%)$ coefficient was considered strong $(0.6<\mathrm{r}<0.9)$, according to the classification of the correlation coefficients suggested by CARVALHO et al. (2004). When many characters are correlated, as observed in the present study, the simple correlation coefficient may result in incomplete information, because a high correlation between two characters may be due to the influence that the third character has on these two characters (CRUZ \& REGAZZI, 1997). However, the only correlation regarded as strong (CARVALHO et al., 2004) occurred between two characters of the same group, which were HM and CA of Group2 (Table 2). For this reason, the use of a more effective evaluation is recommended in order to determine the best correlations between the groups evaluated. In this case, the use of a canonical correlation, which is more efficient for the study of relationships, is advised, as it is applicable to a large number of characters (HAIR JUNIOR et al., 2009).

When using all characters presented in table 1 , the co-linearity estimated by the number of conditions, which is the ratio between the higher and the lower self-value of the correlations' matrix, was rated as weak (MONTGOMERY et al., 2006), within each group of characters; being non-restrictive to estimate coefficients of canonical pairs. Thus, in table 3, it is possible to observe that the coefficients of canonical correlation between the characters of Groups 1 and 2 showed significance at the chi-square test $(\mathrm{P}<0.05)$, in the first-order canonical pair, which is the pair of interest in this study. It was also observed that the correlation for this pair was high $(r=0.58)$ and that the groups that were evaluated are not independent.

Coefficients of the first canonical pair, observed in table 3 , established the inter-group relations. Plants were classified, in descending order, as plants with more leaves on the 58DAT (0.63) and a larger stem diameter on the 58DAT (0.53). These are the most significant traits that result in plants with a higher head mass at harvest (1.23). The other characters had a limited contribution in regards to both characters of final production (HMandCA). Therefore, it is possible to state that, in the initial phases of field cultivation, the 17 and 21DAT, the variations in the plant's characteristics are not determining of the variation of the plant's final production. Even if the plants 
Table 2 - Estimates for the Pearson's correlation coefficients between the characters of broccoli BRO $68^{\circledR}$ hybrid.

\begin{tabular}{|c|c|c|c|c|c|c|c|}
\hline Char $^{(1)}$ & $\mathrm{HM}$ & $\mathrm{CA}$ & PH21 & PH58 & NL21 & NL58 & SH21 \\
\hline $\mathrm{CA}$ & $0.83^{*}$ & & & & & & \\
\hline PH21 & $0.21^{*}$ & $0.19^{* *}$ & & & & & \\
\hline PH58 & $0.13^{*}$ & 0.04 & 0.06 & & & & \\
\hline NL21 & $0.11^{*}$ & $0.13^{*}$ & $0.29^{* *}$ & 0.01 & & & \\
\hline NL58 & $0.31^{*}$ & $0.14^{* *}$ & 0.06 & $0.18^{* *}$ & -0.07 & & \\
\hline $\mathrm{SH} 21$ & 0.03 & 0.01 & $0.38^{* *}$ & -0.04 & $0.40^{* *}$ & -0.48 & \\
\hline SH58 & $0.19^{*}$ & $0.17^{* *}$ & $0.19^{* *}$ & $0.24^{* *}$ & $0.21^{* *}$ & $-0.12^{*}$ & $0.31^{* *}$ \\
\hline $\mathrm{SD} 21$ & $0.31^{*}$ & $0.31^{* *}$ & $0.36^{* *}$ & -0.01 & $0.24^{* *}$ & 0.03 & $0.10^{*}$ \\
\hline SD58 & $0.33^{*}$ & $0.26^{* *}$ & 0.06 & -0.07 & $0.20^{* *}$ & -0.1 & 0.06 \\
\hline LA17 & 0.18 & $0.23^{* *}$ & $0.27^{* *}$ & -0.05 & $0.32^{* *}$ & -0.03 & $0.26^{* *}$ \\
\hline LA32 & $0.20^{* *}$ & $0.22^{* *}$ & $0.25^{* *}$ & -0.05 & $0.31^{* *}$ & $-0.19^{* *}$ & $0.25^{* *}$ \\
\hline
\end{tabular}

${ }^{*}$ Significant through t test $(\mathrm{P}<0.05) ;{ }^{* *}$ significant through $\mathrm{t}$ test $(\mathrm{P}<0.01) ;{ }^{(1)} \mathrm{HM}-$ head mass at harvesting; CA - canopy area; PH21 - plant height on the 21DAT;PH58 - plant height on the 58 DAT; NL21- number of leaves on the 21 DAT; NL58 - number of leaves on the 58 DAT; SH2 1 - stem height on the 21 DAT; SH58 - stem height on the 58 DAT; SD21 - stem diameter on the 21 DAT; SD 58 - stem diameter on the 58 DAT; LA17 - leaf area on the 17 DAT; LA 32 - leaf area on the 32 DAT.

showed few leaves or a reduced stem diameter in this development phase, the successful cultivation practices and adequate management may provide a good final production of these plants. In the initial stages of cultivation, these characteristics are no determining of final productivity.

Conversely, it is possible to estimate the production through some observed characters, stem diameter on the 58DAT (SD58) and the number of leaves on the 58DAT (NL58) (strongly determining the HM), which can be useful to estimate production before harvesting. For this purpose, it is necessary for the HM to be based on the SD58 and NL58, using regression models. Even without the application of regression analysis, in situations in the field, the farmer may estimate which plants will reach a higher HM, observing only the plant's quantity of leaves in this development phase. Characters that show negative values in the analysis of canonical coefficients (Table 3) show an inverse relationship to the characters of the other group.

The NL58 was the character with the higher canonical weight in the production of broccoli (0.64). Such fact occurred because of the higher quantity of a photo synthetically active area, increasing the light interception, resulting in an increased production. According to TREVISAN (2013), the peculiarity of this hybrid in regards to the spiral distribution of leaves throughout the stem and the greater width of the limb, when compared to other hybrids, allow a straighter insertion angle of the stem, resulting in greater incidence of radiation, which consequently increases the average mass of the heads. In a study conducted by DINIZ et al. (2008), a greater correlation between the number of leaves and the dry matter of heads was found, a trait that is intimately related to the mass of fresh head.

A higher SD58 indicates plants with a more robust structure that support more weight and production, being less sensitive to tipping and fall of the stem, due to winds or other factors. In addition, a higher stem diameter provides a greater vascularization with an increased supply of water and nutrients. Thus, plants that have a greater stem diameter, have a better production rate when compared to others, as also observed in the study conducted by TREVISAN (2013). The character SD58 showed the second higher canonical weight in Group 1, a determining factor of HM. DINIZ et al. (2008) also recommend the stem diameter when inferring about the growth of broccoli.

\section{CONCLUSION}

The highest linear correlation $(\mathrm{r}=0.83)$ was obtained between the head mass and the canopy area of broccoli. At the initial stages of cultivation, 17 and 21 days after transplanting, the variations in the plant's characteristics are not determining of the variation in the plants' final production. A greater number of leaves and a larger stem diameter on the 58 day after transplanting determine the greater mass of the broccoli head. 
Table 3 - Canonical correlation coefficient (CC), Chi-square test values, degrees of freedom (DF), probability of CC significance and coefficients of the first canonical pair (PC1) for both groups of characters defined for the broccoli BRO $68^{\circledR}$ hybrid.

\begin{tabular}{|c|c|c|c|c|}
\hline Canonical Pair & $\mathrm{CC}$ & Chi-square & DF & Probability $(\%)$ \\
\hline 1 & 0.58 & 173.88 & 20 & $0.01^{*}$ \\
\hline 2 & 0.28 & 29.37 & 9 & $0.06^{\mathrm{ns}}$ \\
\hline Group & Character (acror & & & PC1 \\
\hline \multirow{2}{*}{ Group 2} & \multicolumn{3}{|c|}{ Head mass at harvesting (HM) } & 1.24 \\
\hline & \multicolumn{3}{|c|}{ Canopy area (CA) } & -0.30 \\
\hline \multirow{10}{*}{ Group 1} & \multicolumn{3}{|c|}{ Number of leaves on the 58DAT (NL58) } & 0.64 \\
\hline & \multicolumn{3}{|c|}{ Stem diameter on the 58DAT (SD58) } & 0.53 \\
\hline & \multicolumn{3}{|c|}{ Stem height on the 58DAT (SH58) } & 0.25 \\
\hline & \multicolumn{3}{|c|}{ Stem diameter on the 21DAT (SD21) } & 0.25 \\
\hline & \multicolumn{3}{|c|}{ Leaf area on the 17DAT (LA17) } & 0.14 \\
\hline & \multicolumn{3}{|c|}{ Stem height on the 21DAT (SH21) } & -0.12 \\
\hline & \multicolumn{3}{|c|}{ Plant height on the 21DAT (PH21) } & 0.12 \\
\hline & \multicolumn{3}{|c|}{ Plant height on the 58DAT (PH58) } & 0.12 \\
\hline & \multicolumn{3}{|c|}{ Leaf area on the 32DAT (LA32) } & 0.10 \\
\hline & \multicolumn{3}{|c|}{ Number of leaves on the 21DAT (NL21) } & -0.07 \\
\hline
\end{tabular}

\section{ACKNOWLEDGEMENTS}

The authors thank the Conselho Nacional de Desenvolvimento Científico e Tecnológico (CNPq) for financial support and the concession of a undergraduate's scholarship to the first author.

\section{REFERÊNCIAS}

ALVES, N.E.G. et al. Efeito dos diferentes métodos de cocção sobre os teores de nutrientes em brócolis (Brassica oleracea $\mathrm{L}$. var. italica). Revista do Instituto Adolfo Lutz, v.70, p.507-513, 2011. Available from: <http://periodicos.ses.sp.bvs.br/pdf/rial/v70n4/ v70n4a10.pdf>. Accessed: May 22, 2015.

BRUM, B. et al. Correlações canônicas entre variáveis de semente, plântula, planta e produção de grãos em mamoneira. Ciência Rural, v.41, p.404-411, 2011. Available from: $<$ http://www.scielo. br/pdf/cr/v41n3/a886cr3922.pdf>. Accessed: May 22, 2015. doi: 10.1590/S0103-84782011000300007.

CAMPAGNOL, R. et al. Boro e nitrogênio naincidênciadehastes ocas e no rendimento de brócolis. Ciência e Agrotecnologia, v.33, p.1477-1485, 2009. Available from: <http:// www.scielo.br/scielo.php?script=sci_arttext $\&$ pid $=$ S1413-70542009000600004 $>$. Accessed: May 22, 2015. doi: $10.1590 / \mathrm{S} 1413-70542009000600004$.

CARGNELUTTI FILHO, A. et al. Tamanho de amostra para estimação do coeficiente de correlação linear de Pearson entre caracteres de milho. Pesquisa Agropecuária Brasileira, v.45, p.1363-1371, 2010. Available from: <http://www.scielo.br/pdf/ pab/v45n12/v45n12a05.pdf $>$. Accessed: May 22, 2015. doi: 10.1590/S0100-204X2010001200005.
CARVALHO, F.I.F. et al. Estimativas e implicações da correlação no melhoramento vegetal. Pelotas: UFPel, 2004. 142p.

CARVALHO, P.G.B. et al. Hortaliças como alimentos funcionais. Horticultura Brasileira, v.24, p.397-404, 2006. Available from: $<$ http://www.scielo.br/pdf/hb/v24n4/01.pdf>. Accessed: May 22, 2015. doi: 10.1590/S0102-05362006000400001.

CASTRO, A.F.N.M. et al. Análise multivariada para seleção de clones de eucalipto destinados à produção de carvão vegetal. Pesquisa Agropecuária Brasileira, v.48, p.627-635, 2013. Available from: $<$ http://www.scielo.br/pdf/pab/v48n6/08.pdf >. Accessed: May 22, 2015. doi: 10.1590/S0100-204X2013000600008.

CRUZ, C.D. Genes - a software package for analysis in experimental statistics and quantitative genetics. ActaScientiarum Agronomy, v.35, p.271-276, 2013. Available from: $<$ http://www. scielo.br/pdf/asagr/v35n3/v35n3a01.pdf $>$. Accessed: May 22, 2015. doi: 10.4025/actasciagron.v35i3.21251.

CRUZ, C.D.; REGAZZI, A.J. Modelos biométricos aplicados ao melhoramento genético. 2.ed. Viçosa: UFV, 1997. 390p.

DINIZ, E.R. et al. Crescimento e produção de brócolis em sistema orgânico em função de doses de composto. Ciência e Agrotecnologia, v.32, p.1428-1434, 2008. Available from: <http:// www.scielo.br/pdf/cagro/v32n5/11.pdf $>$. Accessed: May 22, 2015. doi: 10.1590/S1413-70542008000500011.

EMBRAPA (EMPRESA BRASILEIRA DE PESQUISA AGROPECUÁRIA). Sistema brasileiro de classificação de solos. 2.ed. Rio de Janeiro: CNPS, 2006. 306p.

FERREIRA, D.F. Estatística básica. 2. ed. Lavras: UFLA, 2009. 664p. 
FERREIRA, S. et al. Produtividade de brócolis de verão com diferentes doses de bokashi. Revista Agrogeoambiental, v.5, p.3138, 2013. Available from: <http://agrogeoambiental.ifsuldeminas. edu.br/index.php/Agrogeoambiental/article/view/487/489>. Accessed: May 22, 2015.

GODOY, W.I.; RECH, R. Aspectos socioeconômicos e de produção relacionados às feiras-livres do Sudoeste do Paraná. Revista Brasileira de Agroecologia, v.8, p.40-47, 2013. Available from: <http:/www. aba-agroecologia.org.br/revistas/index.php/rbagroecologia/article/ view/10424/8854>. Accessed: May 22, 2015.

HAIR JUNIOR, J.F.et al. Análise multivariada de dados. Porto Alegre: Bookman, 2009. 688p.

KRAUSE, M.V.; MAHAN, L.K. Alimentos, nutrição e dietoterapia. São Paulo: Roca, 2005. 981p.

LALLA, J.G. et al. Competição de cultivares de brócolos tipo cabeça única em Campo Grande. Horticultura Brasileira, v.28, p.360-363, 2010. Available from: <http://dx.doi.org/10.1590/ S0102-05362010000300020>. Accessed: May 22, 2015. doi: $10.1590 / \mathrm{S} 0102-05362010000300020$.

MAACK, R. Geografia física do Estado do Paraná. Curitiba: UEPG, 1968. 350p.

MELO, R.A.C. et al. Cultivo de brócolos de inflorescência única no verão em plantio direto. Horticultura Brasileira, v.28, p.2328, 2010. Available from: <http://dx.doi.org/10.1590/S010205362010000100005>. Accessed: May 22, 2015. doi: 10.1590/ S0102-05362010000100005.

MONTGOMERY, D.C. et al. Introduction to linear regression analysis. New York: John Wiley, 2006. 612p.
MORRISON, D.F. Multivariate statistical methods. 2.ed. Tokyo: McGraw Hill, 1978. 415p.

OLFATI, J.A. et al. An estimation of individual feaf area im cabbage and broccoli using non-destructive methods. Journal of Agricultural Science and Technology, v.12, p.627-632, 2010

RIGÃO, M.H. et al. Correlação canônica entre caracteres de tubérculos para seleção precoce de clones de batata. Ciência Rural, v.39, p.2347-2353, 2009. Available from: <http://www. scielo.br/pdf/cr/v39n8/a325cr1750.pdf>. Accessed: May 22, 2015.

SEABRA JUNIOR, S. et al. Produção de cultivares de brócolis de inflorescência única em condições de altas temperaturas. Horticultura Brasileira, v.32, p.497-503, 2014. Available from: <http://dx.doi.org/10.1590/S0102053620140000400021>. Accessed: May 22, 2015. doi: 10.1590/ S0102-053620140000400021.

TAVARES, M. et al. Efeitos diretos e indiretos e correlações canônicas para caracteres relacionados com a produção de pimentão. Bragantia, v.58, p.41-47, 1999. Available from: <http:// www.scielo.br/pdf/brag/v58n1/0979.pdf $>$. Accessed: May 22, 2015. doi: 10.1590/S0006-87051999000100006.

TREVISAN, J.N. Crescimento, desenvolvimento e produção de brócolis de cabeça única. 2013. 105f. Dissertação (Mestrado em Agronomia) - Curso de Pós-graduação em Agronomia, Universidade Federal de Santa Maria, RS.

TREVISAN, J.N. et al. Rendimento de cultivares de brócolis semeadas em outubro na região centro do Rio Grande do Sul. Ciência Rural, v.33, p.233-239, 2003. Available from: <http:// www.scielo.br/pdf/cr/v33n2/15211.pdf >. Accessed: May 22, 2015. doi: 10.1590/S0103-84782003000200009. 